\title{
スラグ中ふっ素分析方法の開発
}

柳原和夫*，儀賀義勝*

\section{Development of Analysis Method of Fluorine in Slag}

\author{
Kazuo Yanagihara and Yoshikatsu Giga
}

\section{Synopsis}

Fluorite is added to steelmaking slag to improve fluidity and desulfurization reaction. Leaching of fluorine to soil, however, is regulated by notification of environmental ministry and is the tasks to be settlement in slag recycle. It is necessary to know a quantity of fluorine in slag correctly in order to solve above problem.

Therefore, rapid analysis method of accurate fluorine quantity in slag is developed. This analysis method is extracts fluorine from slag by pyrohydrolysis, and to measure the fluorine with ion chromatograph.

Addition of tungsten trioxide as reaction accelerator and heated at $1100{ }^{\circ} \mathrm{C}$ for over ten minutes as the pyrohydrolysis condition which completely extracted fluorine is adopted in this method.

Quantity of fluorine analysis method has developed and shows good accuracy and compatible with good efficiency. It is revealed from the fact that this analysis method could analyze a quantity of fluorine with twenty samples automatically and the accuracy was about $2 \%$ relative standard deviation.

\section{1. 緒言}

製鋼スラグには流動性を向上させ, 脱硫反応を促進させ るために，蛍石が添加される。そのスラグを路盤材などと して有効利用するためには,ふっ素の土壤への溶出を抑制 し, 環境污染を防止する必要がある。

2001 年土壤の污染に係る環境基準にふっ素とほう素が 追加され，2005 年に路盤材などに用いるスラグの溶出量 などの試験方法として, スラグ類の化学物質試験方法 ${ }^{1)}$ が 規格化された。

製鋼スラグからのふっ素溶出量の抑制技術を開発する ためには, 基準となるスラグ中の全ふっ素含有量を正確に 把握し, 溶出量などと比較する必要がある.

スラグ試料に, 最も一般的に用いられているランタンー アリザリンコンプレキソン吸光光度法においては陽イオ ンの影響が大きく，特にアルミニウム，カドミウム，コバ ルト，鉄，ニッケル，ベリリウム，鉛などが妨害するの で, あらかじめ蒸留してふっ化物イオンを分離する必要が
ある 2) 4).

一方, Warf らが開発したふっ素分離法では, $1000{ }^{\circ} \mathrm{Cに}$ 加熱した反応管に加熱水蒸気を通じ, 難溶性あるいは蒸留 法ではふっ素の分離が困難な試料から, 熱加水分解により ふっ素をふっ化水素酸として分離することができた。ま た, ふっ素の分離が困難な塩基性度の高い試料も, 三酸化 タングステンなどのような酸性酸化物を混ぜることによ

り，容易に分離できる5).

さらに, 渡辺ら 6) は, 窒化けい素原料粉末または焼結 体粉砕品をあらかじめ $1350{ }^{\circ} \mathrm{C}$ に加熱した石英管内に挿入 L, $4 \mathrm{ml} / \mathrm{min}$ で水蒸気を送り込み, ふっ素を熱加水分解し て水酸化ナトリウム溶液に吸収させ, イオンクロマトグラ

フ（Ion Chromatogrph：以下 IC）で定量している.

本研究では，この熱加水分解と IC の組合せを自動化し， スラグ中ふっ素の最適な分析条件を検討して, 精度が良好 でかつ分析操作の安易な定量方法を開発した. 


\section{2. 実験方法}

\section{1 実験装置}

実験には Fig.1 に示す，(株)ダイアインスツルメンツが開 発した, 熱加水分解 $\rightarrow$ 吸収を自動化した自動試料燃焼装置 (AQF-100 型) と，Dionex 社の IC（ICS1500）を組み合せ た装置を用いた。その分析装置はFig.2に示すように，以 下に述べる 4 ユニットから構成されている.その主な仕様 は以下のとおりであり，各ユニットを連動させて PCで制 御することによって，自動測定される.

(1) 自動試料供給装置

円形のパレット上に，最大 20 個のアルミナ製ボートを 並べておき, 順次アルミナ製ボートを掴んで試料供給口に 挿入する.
試料供給口に挿入されたアルミナ製ボード(全長 $45 \mathrm{~mm}$ ×幅 $10 \mathrm{~mm} \times$ 高さ $7 \mathrm{~mm}$ ) は, ボートコントローラーで石 英管の入り口付近から中心部まで4ヶ所の指定位置まで任 意移動でき, 試料加熱温度を調節できるようになっている が, スラグ試料の場合温度制御は必要ないため中心部一ヶ 所とした。

(2) 熱加水分解炉

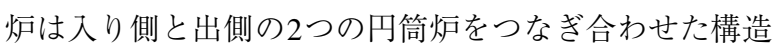
になっており，それぞれ個別に温度を設定できるように なっているが, 炉内を一定の温度で制御するため, どちら も同一温度に設定した. 円筒炉の中心を通る石英の反応管 は, 内管と外管の二重構造になっており，内管にアルミナ 製ボートに入れられた試料が挿入される。ガスは Fig.2に 示す 3 か所から導入され, 内管の先端からは, 始めはアル

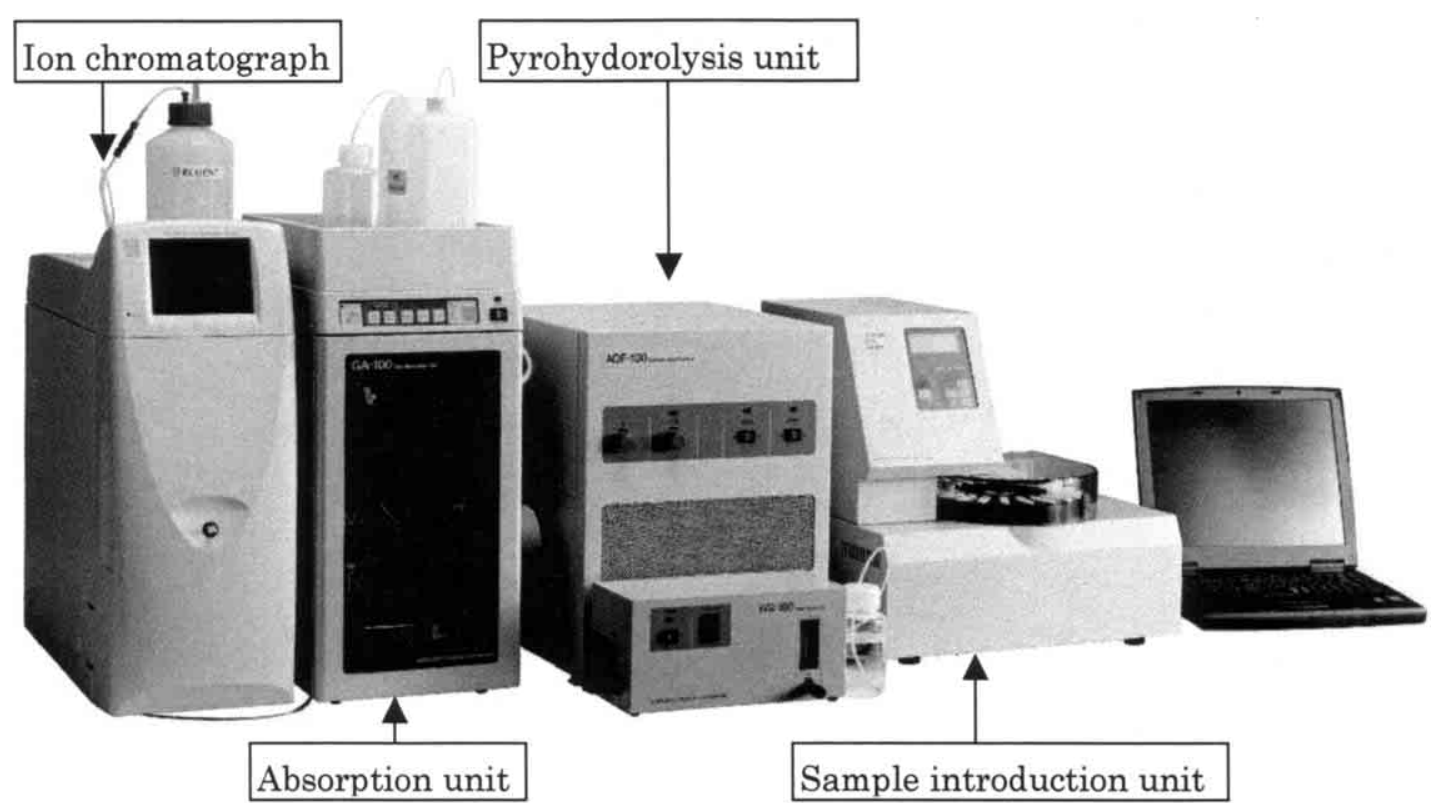

Fig.1. The appearance of the analyzer used for test (AQF-100+ICS1500).

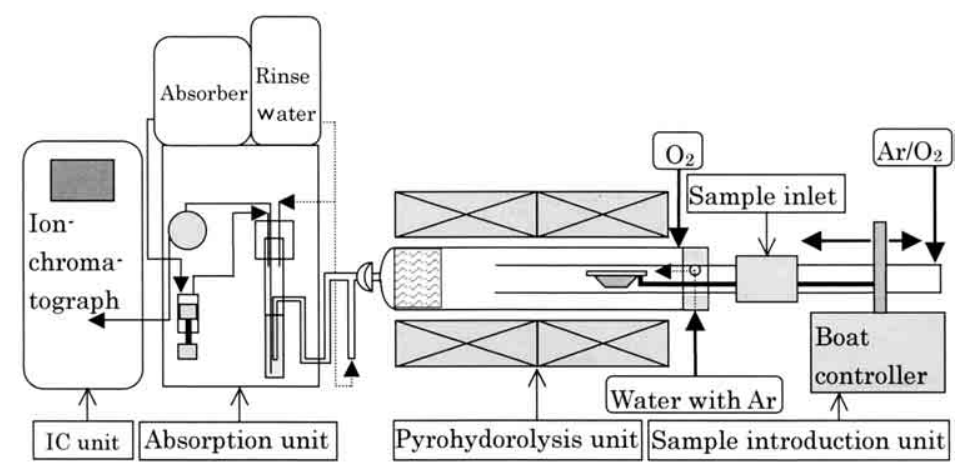

Fig.2. Structure of pyrohydrolysis unit (AQF-100). 
ゴンガスが供給されているが, 試料が導入された後に酸素 ガスに切り替わる。また給水ユニットは小型のプラン ジャーポンプで, アルゴンガスに直接超純水が注入され る.その量はポンプの駆動回数をダイヤル制御することに より替えられ, 加水されたアルゴンガスは内管の上部の孔 から内管に入り，試料に吹き掛けられる。

(3) 吸収部

熱加水分解されたふっ化水素酸は, ガスとともに吸収管 に導かれ, 定量注入された吸収液中をバブリングすること によって吸収される。吸収液としてはふっ素含有率に合わ せて, 内標準として用いたりん酸イオン添加量（りん濃 度: 以下 $\mathrm{P}$ ) を変え, 低濃度用吸収液 $(\mathrm{P}: 1 \mathrm{mg} / \mathrm{l}$, IC 溶離 液組成) と高濃度用吸収液 (P:25 mg/l, IC 溶離液組成) を使い分けた。また溶離液組成に合わせたのは，IC 測定 におけるウォータディップを抑えるためである.

熱加水分解反応が終了すると, 反応管 (外管) にボール ジョイントで接続したガラス管に洗浄液が供給されて管 内を洗浄するとともに, 試料溶液を十分に擋挥する。この 際の液量は試料ごとに若干異なるため, その液量を補正す る目的で内標準法を採用した。 その後試料溶液は, 定量注 入バルブを経由して ICに送られる。

(4) IC

IC のカラムは Dionex 社製で, 分離カラムに IonPac AS12A，ガードカラムに IonPac AG12A，サプレッサに ASRS - URUTRA2 を用いた。

検量線は標準溶液のみを直接 ICに打ち込み作成する. 実試料の測定では熱加水分解に供した試料量を PC に入力 し，自動計算される。

\section{2 試料の前処理}

塊状のスラグ試料を採取し, 鉄製の乳鉢で粗粉砕後, ディスク型振動ミルを用いて粉砕し, 試料の粒度を
$200 \mu \mathrm{m}$ 以下とした.

\section{3 測定方法}

分析条件を Table 1 に示した.アルミナ製ボートは特殊 形状のため高価であったことから, その中に入るニッケル 製の容器を作成して, 使い捨て用にした. そのニッケル容 器に反応促進剂としてキシダ化学製・有機元素分析用·三 酸化タングステン $\left(\mathrm{WO}_{3}\right)$ 粉末を約 $100 \mathrm{mg}$ はかり取り, そ の上に試料粉末をふっ素含有率により Table 1 に示した量 で, $0.01 \mathrm{mg}$ の桁まではかり取って, ミクロスパーテルで 良くかき混ぜる。アルミナ製ボートをターンテーブルに セットし, 事前に設定したパラメーターに従い自動分析し た.

IC の測定は, 試料溶液を $20 \mu 1$ 導入し, 導入後約 $2.2 \mathrm{~min}$ に現れるふっ素イオンピークと約 $11 \mathrm{~min} に$ 現れる内標準 のりん酸イオンピークを測定し, その面積の比と試料はか り取り量からふっ素含有率 (mass\%) を求める.

アルミナ製ボートはブランク低減のため, あらかじめ ニッケル容器とともに, 熱加水分解時と同一条件で $2 \mathrm{~min}$ 程度空焼きを実施する。

反応促進剤として三酸化タングステン $\left(\mathrm{WO}_{3}\right)$ 粉末を用 いた場合, IC に $\mathrm{WO}_{3}$ イオンのピークが $30 \mathrm{~min}$ 弱に現れる ため, ICの測定時間をそれ以下にすることはできない.た だし, 連続分析する場合には, 前試料の IC 測定の終了時 間に合わせて, 次の試料の吸収液の準備, 熱加水分解 - 吸 収を終了するように設定しておけば, IC 測定が連続して 行えるので，能率よく分析することができる.

本法は, 先に述べたように内標準法を採用した. 内標準 として用いたりん酸イオンは, りん酸二水素カリウム $\left(\mathrm{KH}_{2} \mathrm{PO}_{4}\right)$ で調製した。

IC の溶離液は炭酸ナトリウム $\left(\mathrm{Na}_{2} \mathrm{CO}_{3}\right): 2.7 \mathrm{mmol}$ と炭 酸水素ナトリウム $\left(\mathrm{NaHCO}_{3}\right): 0.3 \mathrm{mmol}$ の混合液を使用した.

Table 1. Analytical condition of fluorine content in slag by pyrohydrolysis / ion chromatography.

\begin{tabular}{l|c|c|c}
\hline \multicolumn{1}{c|}{ Parameter } & \multicolumn{3}{c}{ Level } \\
\hline Analysis object substance & \multicolumn{2}{|c}{ Steelmaking slag } & Fluorite \\
\hline Fluorine content range (mass\%) & $\sim 2.5$ & $2.5 \sim 25$ & $25 \sim 50$ \\
\hline Sample weight $(\mathrm{mg})$ & \multicolumn{2}{|c}{$10 \sim 20$} & $10 \pm 2$ \\
\hline Analytical curve renge $(\mathrm{mg} / \mathrm{l})$ & $0 \sim 25$ & $0 \sim 250$ \\
\hline Furnace temperature $\left({ }^{\circ} \mathrm{C}\right)$ & \multicolumn{3}{|c}{ Inlet: 1100, Outlet:1100 } \\
\hline Pyrohydrolysis time $(\mathrm{sec})$ & \multicolumn{3}{|c}{$>600(960)$} \\
\hline Reaction accelerator $(\mathrm{mg})$ & \multicolumn{3}{|c}{$\mathrm{WO}_{3}: 100 \pm 10$} \\
\hline Quantity of water supply $(\mathrm{ml} / \mathrm{min})$ & \multicolumn{3}{|c}{$0.12 \sim 0.23(0.18)$} \\
\hline Quantity of absorber $(\mathrm{ml})$ & \multicolumn{3}{|c}{20} \\
\hline
\end{tabular}




\section{3. 実験結果および考察}

\section{1 熱加水分解条件の検討}

熱加水分解条件の検討には, Table 2 に示す実際のスラ グ試料（5 種類）を主に用いた. 要因として, 加熱温度・ 熱加水分解時間 - 反応促進剂の添加量 - 加水量 · 試料量の 影響およびそれらの相互作用が考えられるが,ここではそ れぞれの因子について個別に, 以下の検討を実施した。

(1) 加熱温度

一般的に熱加水分解は高温で実施されることが多いが, 本装置の管状炉設定温度は入り側・出側ともに上限が 1100 ${ }^{\circ} \mathrm{C}$ とれている。 そこでまず，スラグ試料の場合 $1100{ }^{\circ} \mathrm{C}$ 加熱で十分かどうかを調査した．その結果，1000 ${ }^{\circ} \mathrm{Cでは}$ やや低值を示すが, $1050{ }^{\circ} \mathrm{C}$ と $1100{ }^{\circ} \mathrm{C}$ 加熱ではあまり差が

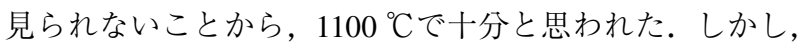
念のためメーカーに依頼して $1200{ }^{\circ} \mathrm{C}$ ま゙炉の温度を上げ て分析し, Fig.3に示したように $1100{ }^{\circ} \mathrm{C}$ 加熱と差が無いこ とを確認した.この結果から, $1100{ }^{\circ} \mathrm{C}$ 加熱温度として採 用した。

\section{(2) 熱加水分解時間}

試料を炉内で熱加水分解する時間を調査した. 各熱加水 分解時間で分析した後の試料中のふっ素残存量を調べた 結果, Table 3 に示したように, $480 \mathrm{sec}$ 以下では 1 部の試 料で微量のふっ素の残存が認められたが， $600 \mathrm{sec}$ 以上で はふっ素の残存が全く認められなかったため, $600 \mathrm{sec}$ 以 上にすることにした．実際には IC の測定に時間がかかる ことから, 熱加水分解時間を長くしても全体の分析時間に

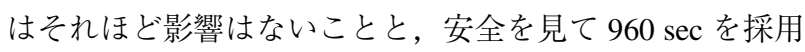
した。
このように熱加水分解法によるふっ素の分離時間は, 蒸 留分離法の約 $1 \mathrm{~h}$ に比べかなり短縮できる。またそれを自 動化できたことから, 能率および作業性に優れた方法であ る.

(3) 反応促進剤の添加量

反応促進剤として三酸化タングステン $\left(\mathrm{WO}_{3}\right)$ 粉末を, 無 添加, $50 \mathrm{mg}$ および $100 \mathrm{mg}$ 添加してふっ素分析值を比較 した。その結果，Fig.4に示したように，無添加では明ら かに低值を示したが, $50 \mathrm{mg}$ と $100 \mathrm{mg}$ 添加のふっ素分析 值に大きな差がなかったことから, 安全を見て $100 \mathrm{mg}$ 添 加することにした。

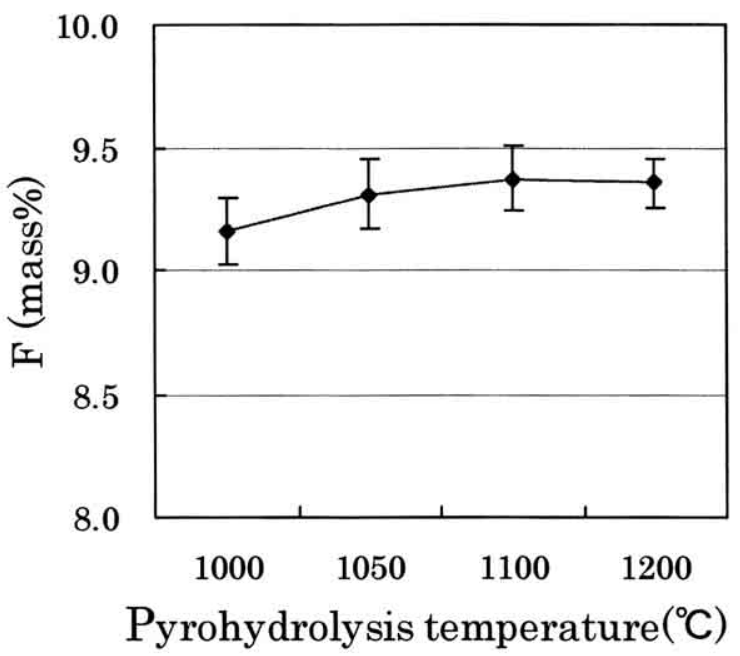

Fig.3. Effect of pyrohydrolysis temperature on analytical value of fluorine in slag sample $\mathrm{E}$.

Table 2. Chemical composition of the slag samples.

\begin{tabular}{c|c|c|c|c|c|c|c}
\multicolumn{1}{c}{ (mass\%) } \\
\hline Sample & $\mathrm{FeO}$ & $\mathrm{SiO}_{2}$ & $\mathrm{Al}_{2} \mathrm{O}_{3}$ & $\mathrm{CaO}$ & $\mathrm{MgO}$ & $\mathrm{Cr}_{2} \mathrm{O}_{3}$ & $\mathrm{~F}^{*}$ \\
\hline $\mathrm{A}$ & $<0.1$ & 22.3 & 22.8 & 41.0 & 11.9 & $<0.1$ & 0.08 \\
\hline $\mathrm{B}$ & 0.1 & 35.3 & 4.6 & 40.8 & 15.2 & 2.5 & 0.23 \\
\hline $\mathrm{C}$ & 0.2 & 17.8 & 12.7 & 55.5 & 12.7 & 0.2 & 2.93 \\
\hline $\mathrm{D}$ & 0.6 & 20.1 & 4.6 & 60.6 & 5.0 & $<0.1$ & 4.92 \\
\hline $\mathrm{E}$ & 0.2 & 18.3 & 7.8 & 52.6 & 6.8 & 0.1 & 8.15 \\
\hline
\end{tabular}

*Determination of fluorine content by ion chromatography after distillation.

Table 3. Quantity of fluorine in the sample which we analyzed with each pyrohydrolysis time.

\begin{tabular}{c|c}
\hline $\begin{array}{c}\text { Pyrohydrolysis time } \\
(\mathrm{sec})\end{array}$ & $\begin{array}{c}\text { Quantity of fluorine } \\
(\mu \mathrm{g})\end{array}$ \\
\hline 360 & $0 \sim 5$ \\
\hline 480 & $0 \sim 3$ \\
\hline 600 & 0 \\
\hline
\end{tabular}


(4) 加水量

給水ユニットのダイアルを回して, 加水量を変化させ, ふっ素分析值への影響を調べた. その結果, Fig.5 に示し たように $0.07 \mathrm{ml} / \mathrm{min}$ 以下（ダイアル(2)）では明らかに低 值を示すが， $0.12 \mathrm{ml} / \mathrm{min}$ 以上（ダイアル(4)）ではふっ素 分析值が一定になったことから，安全を見て $0.18 \mathrm{ml} / \mathrm{min}$ （ダイアル6）を採用した。

(5) 試料量の影響

IC におけるふっ素イオンの感度が非常に良好なことか ら，スラグのような高含有率試料の場合には，通常は IC 測定前に試料溶液を希釈するが, 本装置にはその機能が無 い.また, 試料溶液の IC 導入量 $(20 \mu 1)$ をこれ以上減ら すことも精度上問題がある.そのため最初の試料はかり取

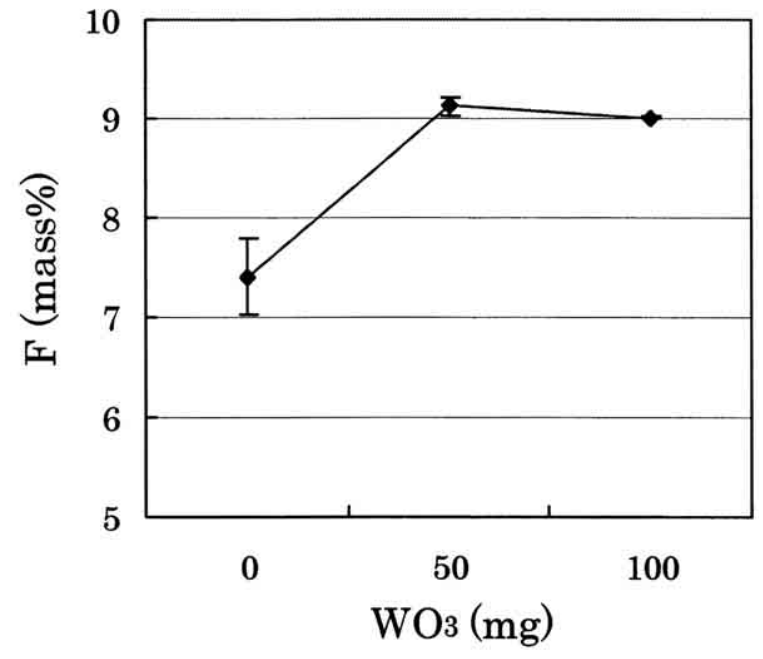

Fig.4. Effect of pyrohydrolysis accelerator $\left(\mathrm{WO}_{3}\right)$ on analytical value of fluorine in slag sample $E$.

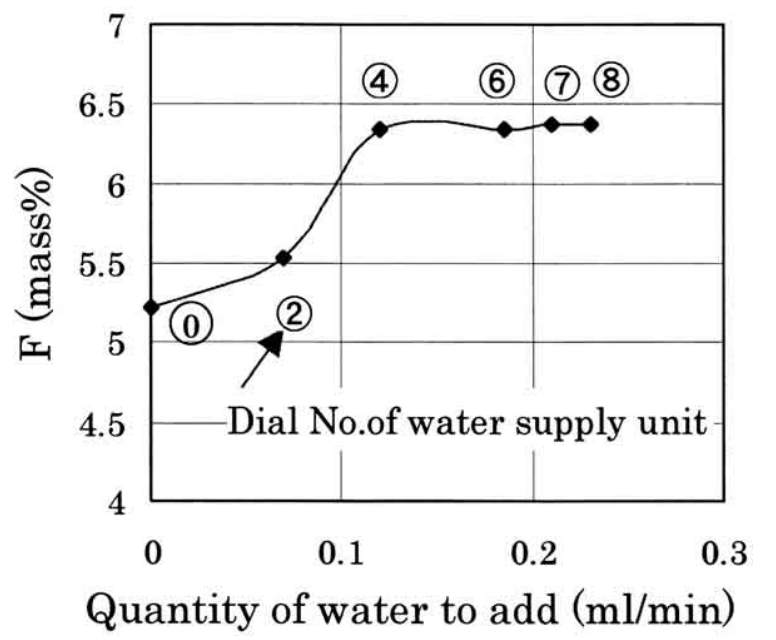

Fig.5. Effect of quantity of water to add to fluorine analytical value in slag sample D.
り量を非常に少なくする必要があり, mg 〜数十 $\mathrm{mg}$ レベ ルでのふっ素分析におよぼす試料量の影響を調査した。そ の結果 Fig.6に示したように, 含有率の異なる 3 試料とも $10 \sim 20 \mathrm{mg}$ で分析が一定になることが分かった．この原 因は, $10 \mathrm{mg}$ 未満では試料のはかりとり量の少なさによる バラツキ, $40 \mathrm{mg}$ では回収率の低下と考えられることから， Table 1 に示したように，スラグ試料の場合には $10 〜 20 \mathrm{mg}$ とした。一方，蛍石のような高含有率の試料については， 検量線の濃度範囲を超えることから約 $10 \mathrm{mg}$ にした。
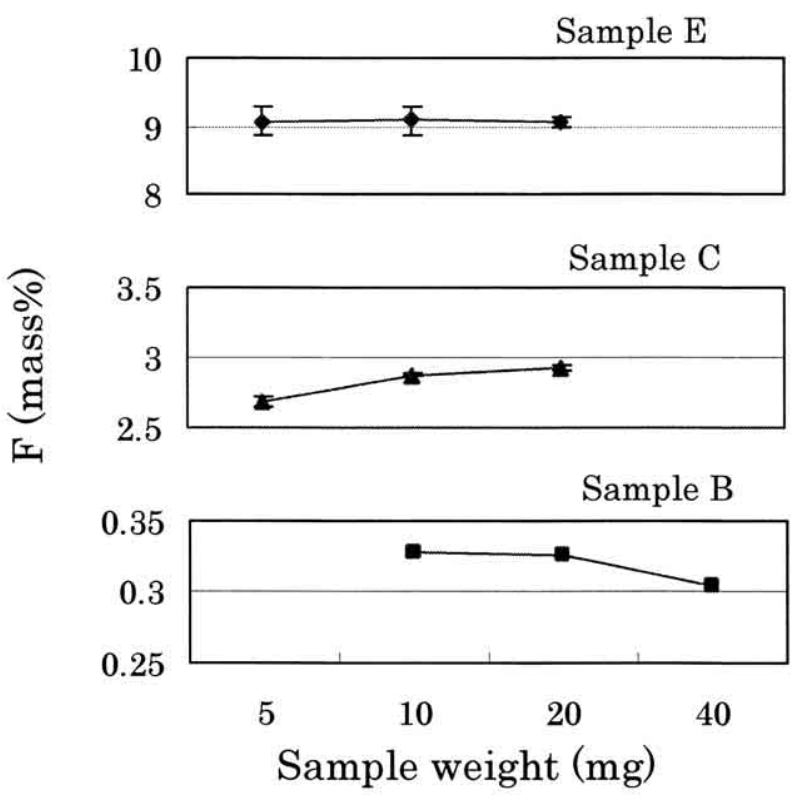

Fig.6. Effect of sample weight on analytical value of fluorine in slag samples.

\section{2 定量精度}

検討した分析条件で，ふっ素含有率の異なるスラグ 15 試料を選択し, 日を変えて 3 回分析して求めたふっ素含有 率と精度の関係を Fig.7 に示した。これより通常のスラグ 中のふっ素は相対標準偏差 (RSD) $2 \%$ 程度の精度で分析 できることが分かった。この結果は, 熱加水分解による ふっ素の回収率がほぼ100\%で安定しているためと推定さ れる。

\section{3 正確さの評価}

Table 2 に示したスラグ試料を酸分解しつつ蒸留した後, ICで測定したふっ素分析值と, 本法での分析值を比較した. その結果，Fig.8に示したように，ふっ素含有率の大きい 試料 D と E は, 蒸留法の方が本法に比べかなり低值を示 している。これは蒸留法において, 回収率が低いためと考 えられる.このことは, 検量線は分離操作を実施していな いため, 分析值に回収率が直接影響することに起因する. 


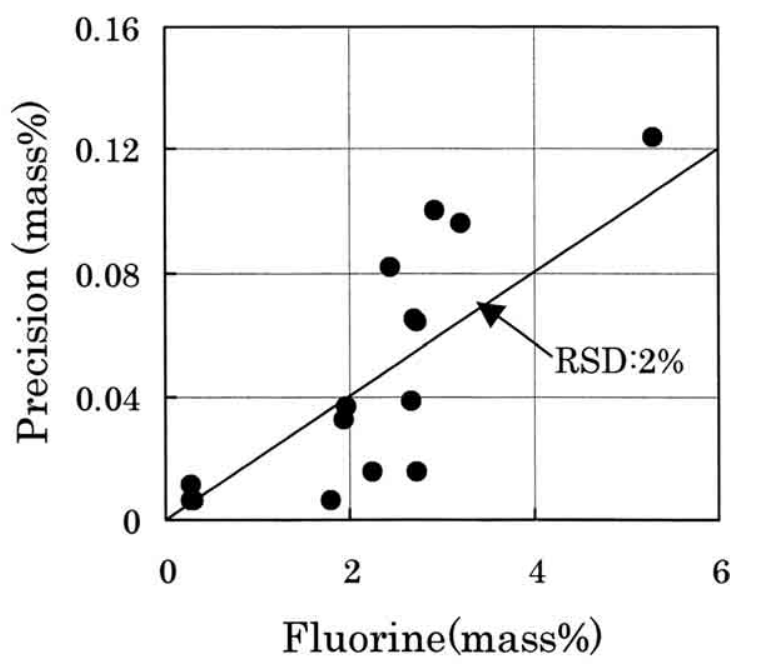

Fig.7. Precision of fluorine analytical value in slag samples.

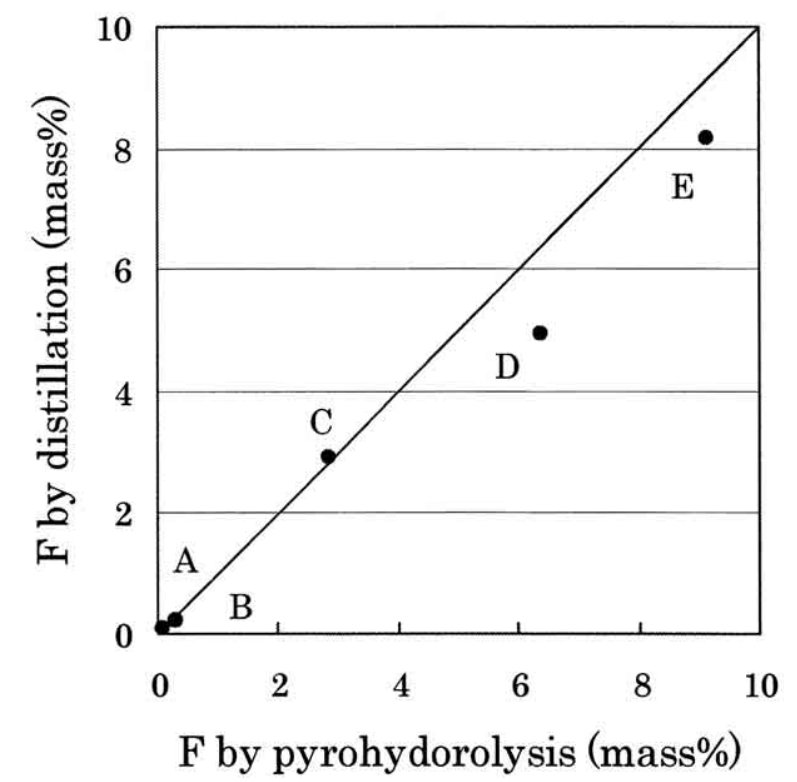

Fig.8. Difference of fluorine analytical value in slag samples between pyrohydrolysis method and distillation method.

また本報で検討した以外の材質の試料についても， Table 4 に示した市販の標準試料により正確さを調べた結
果, 低含有率のポルトランドセメント, 鉄鉱石中のふっ素 から高含有率の蛍石まで標準值と良く一致した.このこと から, 微粉末状酸化物などへの本法適用の可能性は大きい と考えられる.また，試料によっては硫酸イオンや塩素イ オンのピークも見られることから,これらの元素分析への 応用も考えられる。

\section{4. まとめ}

(1) スラグ試料の熱加水分解条件を検討した結果, 以下の 条件で分析できることが分かった。

(1) 加熱温度を $1100{ }^{\circ} \mathrm{C}$

(2) 熱加水分解時間は $960 \mathrm{sec}$

(3) 反応促進剤の添加量は $100 \mathrm{mg}$

(4) 加水量は約 $0.18 \mathrm{ml} / \mathrm{min}$

(5) 試料量は $10 \sim 20 \mathrm{mg}$

(2) 上記分析条件でスラグ中のふっ素が相対標準偏差 $2 \%$ 程度の精度で分析できた。

(3) 同じスラグ試料中ふっ素を, 蒸留後 IC で分析した值 と, 本法での結果を比較すると, 特に高含有率の試料で蒸 留法の方が本法に比べ低值を示しており, 蒸留法における 回収率が低いためと考えられる。このことは, 検量線は分 離操作を実施していないため, 分析值に回収率が直接影響 することに起因する。

(4) 従来の，スラグ試料中のふっ素を蒸留分離し，ランタ ンーアリザリンコンプレキソン吸光光度法で分析する方 法は蒸留分離に時間がかかり，10 件あたり 1.5 日程度かか る.また, 吸光光度法の替わりに ICにすると, 測定作業 は自動化できるが，それでも 1 日以上かかる。 それに対し て, 本法で連続測定する場合には熱加水分解・吸収と IC 測定を併行処理することによって約 2 試料 $/ \mathrm{h}$ 分析でき, 最大 20 試料までを 1 日で自動的に分析できる.

(5) 以上のことから, 本法は蒸留分離法に比べ, 精度と能 率の両方共に良好な分析方法である。

(6) 市販の酸化物系の標準試料により正確さを調べた結 果, 低含有率のポルトランドセメント, 鉄鉱石中のふっ素

Table 4. Analytical result of fluorine in standard samples.

\begin{tabular}{l|c|c|c|c}
\hline \multirow{2}{*}{ Standard } & \multirow{2}{*}{ Materials } & \multirow{2}{*}{$\begin{array}{c}\text { Certified } \\
\text { values (mass\%) }\end{array}$} & \multicolumn{2}{|c}{ Analytical result (mass\%) } \\
\cline { 3 - 5 } & & 0.06 & 0.05 & $\sigma$ \\
\hline NIST 1880a & Portland cement & 0.09 & 0.11 & 0.005 \\
\hline NIST 1881a & Portland cement & 0.29 & 0.32 & 0.002 \\
\hline ES 678-1 & Iron ore & 0.19 & 0.20 & 0.006 \\
\hline ES 681-1 & Iron ore & 34.04 & 34.37 & 0.010 \\
\hline BRM FM & Fluorite & & \\
\hline
\end{tabular}

NIST (National Institute of Standard and Technolgy) ES (European Standard) BRM (Breitlander Reference Material) 
から高含有率の蛍石まで標準值と良く一致した.このこと から, 微粉末状酸化物などへの本法適用の可能性は大きい と考えられる。

謝辞

本研究を遂行するに当たり，1200 ${ }^{\circ} \mathrm{C}$ まで炉の温度を上 げて測定し， $1100{ }^{\circ} \mathrm{C}$ 加熱と差が無いことを確認していた だいた, 株式会社ダイアインスッルメンッの野沢明義氏に 感謝します。また検討用のスラグ試料を提供していただ き, 分析方法についても助言いただきました株式会社大同 分析リサーチの方々に打礼を申し上げます。

\section{(文 献)}

1) JIS K 0058 (2005).

2）平野四蔵:無機応用比色分析 2 , 共立出版株式会社, 1974, 280.

3) JIS K 0102 (1998), 670.

4) 小林 勇:地球科学的試料の化学分析法 1 , 地質調查所 技術部化学課, 1976, 96.

5) J.C.Warf, W.D.Cline, R.D.Tevebaugh:Anal.Chem., 26(1954), 343.

6) 渡辺光義, 生川 章:分析化学, 49(2000), 583. 